Crowder, J. A. \& Harris, M. (1936). Bur. Stand. J. Res., Wash., 16, 475.

Elsworth, F. F. \& Phillips, H. (1938). J.Text. Inst., Manchr, 29, $219 \mathrm{~T}$.

Elsworth, F. F. \& Phillips, H. (1941). Biochem. J. 35, 135.

Feigl, F. (1931). Qualitative Analyse mit Hilfe von Tupfelreaktionen. Leipzig: Akademische Verlagesellschaft.

Harris, M. (1935). Bur. Stand. J. Res., Wash., 15, 63.

Hobson, R. P. (1929). J. chem. Soc. p. 1384.

Horn, M. J., Jones, D. B. \& Ringel, S. J. (1941). J. biol. Chem. 138, 141.

Horn, M. J., Jones, D. B. \& Ringel, S. J. (1942). J. biol. Chem. 144, 87.

Kassell, B. \& Brand, E. (1938). J. biol. Chem. 125, 145.

Lu, G. D. (1939). Biochem. J. 33, 249.

Mease, R. T. (1934). Bur. Stand. J. Res., Wash., 13, 617.

Middlebrook, W. R. \& Phillips, H. (1942). Biochem. J. 36, 428.

Mizell, L. R. \& Harris, M. (1943). Bur. Stand. J. Res., Wash., 30, 47.

Nicolet, B. H. (1931). J J Amer. chem. Soc. 53, 3066.

Phillips, H. (1936). Nature, Lond., 138, 121.

Plimmer, R. H. A. \& Phillips, H. (1924). Biochem. J. 18, 312.
Race, E., Rowe, F. M., Speakman, J. B. \& Vickerstaff, J. (1938). J. Soc. Dy. .Cot., Bradford, 54, 141.

Raynes, J. L. (1926). J. Text. Inst., Manchr, 17, 379 т.

Rutherford, H. A., Harris, M. \& Smith, A. L. (1937). Bur. Stand. J. Res., Wash., 20, 555.

Shinohara, K. (1935a). J. biol. Chem. 109, 665.

Shinohara, K. (1935b). J. biol. Chem. 112, 671, 683.

Sommer, H. (1940). Industr. Engng Chem. (Anal. ed.), $12,368$.

Speakman, J. B. (1933). Nature, Lond., 132, 930.

Speakman, J. B. (1936). J. Soc. Dy. Col., Bradford, 52, 335.

Speakman, J. B. \& Stoves, J. L. (1937). J. Soc. Dy. Col., Bradford, 53, 236.

Speakman, J. B. \& Whewell, C. S. (1936). J. Soc. Dy. Col., Bradford, 52, 380.

Stoves, J. L. (1942). Trans. Faraday Soc. 38, 254.

Sullivan, M. X. \& Hess, W. C. $(1937 a)$. J. biol. Chem. $120,537$.

Sullivan, M. X. \& Hess, W. C. $(1937 b)$. J. biol. Chem. $122,11$.

Trotman, S. R., Trotman, E. R. \& Brown, J. (1928). J. Soc. chem. Ind., Lond., 47, $4 \mathrm{~T}$.

Vickery, H. B. (1940). J. biol. Chem. 132, 325.

\title{
The Action of Alkalis on Wool
}

\section{THE IDENTITY OF THE LANTHIONINE-FORMING AND BISULPHITE-REACTIVE FRACTIONS OF THE COMBINED CYSTINE OF WOOL}

\author{
By H. LINDLEY AND H. PHILLIPS, Wool Industries Research Association, \\ Torridon, Headingley, Leeds 6
}

(Received 29 September 1944)

In a previous investigation (Cuthbertson \& Phillips, 1945) it was shown that the combined cystine of wool could be divided into two, approximately equal, main fractions differing in their rate and mode of reaction with alkalis. One of these fractions could be converted quantitatively into combined lanthionine (Horn, Jones \& Ringel, 1941), whilst the other tended to decompose in a manner, similar to dialanyl cystine dianhydride (Bergmann \& Stather, 1926), each cystine molecule giving two molecules of combined $\alpha$-aminoacrylic acid:
This reactive half, called fraction $(A+B)$, was further divided (Middlebrook \& Phillips, 1942a) into two subfractions: subfraction $A$, giving waterlabile cysteine and $S$-cysteinesulphonate sidechains which reverted to disulphide-S when the bisulphited wool was rinsed with water, and subfraction $B$, giving cysteine and $S$-cysteinesulphonate side-chains which were stable to water.

In the present investigation we have studied the action of solutions of $\mathrm{NaHSO}_{3}$ on wools which have been boiled with neutral and alkaline buffer solutions and have obtained evidence that it is fraction<smiles>CNC(=O)CC[SH]=S=CC=C1NC(=O)C(CCC(NC)C(C)=O)NC1=O</smiles>

It was also shown (Elsworth \& Phillips, 1941; Middlebrook \& Phillips, 1942 $a$ ) that only one-half of the combined cystine of wool would react with $\mathrm{NaHSO}_{3}$ to give cysteine and $S$-cysteinesulphonate side-chains :
$(A+B)$ of the combined cystine which is converted by alkalis into combined lanthionine. The combined $\alpha$-aminoacrylic acid arises from the alkali decomposition of the second half of the combined cystine, called fraction $(C+D)$, which is not converted into

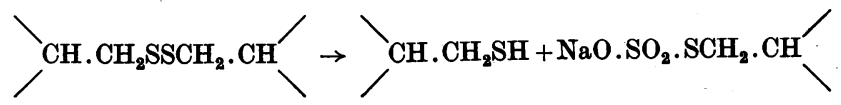


cysteine and $S$-cysteinesulphonate side-chains by $\mathrm{NaHSO}_{3}$ (Middlebrook \& Phillips, 1942a).

\section{METHODS}

The wool used was a commercially scoured and combed merino wool of 64's quality, which was benzene-extracted, rinsed in water, dried and then conditioned, before analysis, in a controlled atmosphere at $21^{\circ}$ and $65 \%$ R.H. Total-S was determined by the Carius method; $\mathrm{SO}_{4}^{=}$and $\mathrm{S}$ or S-compounds oxidized by $\mathrm{Br}$ to $\mathrm{SO}_{4}^{=}$(Br-oxidizable-S) were determined on the acid hydrolysate of the wool $(1 \mathrm{~g}$. boiled in $20 \mathrm{ml} .5 \mathrm{~N}-\mathrm{HCl}$ for $4 \mathrm{hr}$.) by Blumenthal \& Clarke's method (1935); thiol and disulphide-S on the acid hydrolysate by Shinohara's methods (1935 $a, b)$, using a Spekker absorptiometer. Methionine-S was calculated from a determination of methionine (Baernstein, 1936). Similar methods were used for the analyses of the treated wools. All analytical results are calculated on the weight of the anhydrous untreated and treated wools.

Alkali treatment of wool samples. The samples of wool were boiled under reflux for the periods given in Table 1 with 150 times their weight of borate buffers, prepared by dissolving the following constituents in $15 \mathrm{l}$. of water: $\mathrm{pH}$ 7, boric acid (175 g.), borax (17.1 g.), observed $\mathrm{pH}, 7 \cdot 02$; pH 8, boric acid (130 g.), borax (88 g.), observed pH, 8.04; pH 9, boric acid (37 g.), borax (230 g.), observed pH, 8.98; pH 10, borax (172 g.), $\mathrm{NaOH}$ (24 g.), observed pH, 10.00. Samples of wool were also boiled in a similar manner with acid buffers (Table 4) containing in 15 l.: sodium acetate (49.2 g.), acetic acid (144 g.), observed $\mathrm{pH}, 4.06$; sodium acetate (73.8 g.), acetic acid (126 g.), observed pH, 5.12.

During the neutral and alkaline treatments, the $\mathrm{pH}$ of the buffers fell slightly; those at $\mathrm{pH} 7-.9$ by 0.1 unit or less, and that at $\mathrm{pH} 10$ by a maximum of 0.2 unit. After treatment, the wool samples were rinsed in water, until the $\mathrm{pH}$ of the washings was about 7 .

Alkali treatment of stretched wool fibres. When wool fibres are stretched so that their extended length is $30 \%$ greater than their natural length, the configuration of the polypeptide chains changes from the $\alpha$-coiled form to the $\beta$-straight form (Astbury \& Street, 1931). To explain the alterations in the physical properties of wool fibres when treated with alkalis, it has been assumed that the reactivity of the disulphide linkages increases when the fibres are stretched (Astbury \& Street, 1931; Speakman, 1936).

In an attempt to detect this presumed increase in reactivity the wool was boiled in $\mathrm{pH} 8$ buffer whilst extended $30 \%$. For this purpose, a portion of the top wool was spun into a yarn, highly twisted to prevent the fibres slipping over one another during extension. The technical description of the yarn was $1 / 48$ 's with 30 turns/in. The yarn was wound on a stout square frame of stainless steel, one side of which could be moved outwards and held in position by threaded nuts. The yarn passed over this movable side and over the opposite fixed side of the frame. The unstretched yarn $(10 \mathrm{~g}$.) was first immersed in the cold buffer for $17 \mathrm{hr}$., then extended $30 \%$, and the frame placed in 41 . of buffer which was boiled under reflux for $1 \mathrm{hr}$. At the end of this treatment, the tension had decayed and the yarn had acquired a permanent set. It was rinsed in water until the $\mathrm{pH}$ of the water extract was below 7 , and then conditioned.

Treatment of wool samples with $\mathrm{NaHSO}_{3}$. Quadruplicate samples $(0.4 \mathrm{~g}$.) of the untreated and treated wools were thoroughly wetted and then immersed for $17 \mathrm{hr}$. in $30 \%$ (w/v) $\mathrm{NaHSO}_{3}(20 \mathrm{ml}$.). After being squeezed to remove as much $\mathrm{NaHSO}_{3}$ solution as possible, they were hydrolyzed by boiling in $20 \mathrm{ml}$. $5 \mathrm{~N}-\mathrm{HCl}$ for $4 \mathrm{hr}$. During hydrolysis the $S$-cysteinesulphonate group is converted into a cysteine group, so that two cysteine groups arise in the hydrolysate for each disulphide group that has reacted with the $\mathrm{NaHSO}_{3}$ (reaction 2). It was found necessary to boil the hydrolysates until free from all traces of $\mathrm{SO}_{2}$, otherwise the values obtained for the thiol-S were very high and those for the disulphide-S correspondingly low. Samples of the $\mathrm{pH} 8$. treated extended yarn were bisulphited in a similar manner.

The samples of bisulphited wools, prepared as described above, were rinsed during $\frac{1}{2} \mathrm{hr}$. in four changes of tap water, used as a convenient source of a slightly alkaline water (pH 9).

\section{RESULTS}

\section{The S-distributions of wools after boiling with buffers of $\mathrm{pH}$ 7-10}

The S-distributions of the wool before and after boiling in the buffer solutions are given in Table 1.

Table 1. The S-distributions of wool before and after boiling in buffer solutions of $\mathrm{pH}$ 7-10 and the conversion of disulphide-S into lanthionine-S

\begin{tabular}{|c|c|c|c|c|c|}
\hline $\begin{array}{c}\text { Dura- } \\
\text { tion of } \\
\text { treat:- } \\
\text { ment } \\
\text { (hr.) }\end{array}$ & $\begin{array}{c}\text { Thiol- } \\
\text { + disul- } \\
\text { phide-S } \\
(\%)\end{array}$ & $\begin{array}{c}\text { Br-oxidiz- } \\
\text { able-S } \\
+\mathrm{SO}_{4}^{=} \\
\text {as } \mathrm{S} \\
(\%)\end{array}$ & $\begin{array}{c}\text { Total-S } \\
(\%)\end{array}$ & $\begin{array}{l}\text { Lanthio- } \\
\text { nine-S } \\
(\%)\end{array}$ & $\begin{array}{c}\begin{array}{c}\text { Loss of } \\
\text { disul- } \\
\text { phide-S } \\
(\%)\end{array}\end{array}$ \\
\hline o & $3 \cdot 10$ & $0 \cdot 20$ & $3 \cdot 76$ & $0 \cdot 36$ & 0.56 \\
\hline \multicolumn{6}{|c|}{ At $\mathrm{pH} 7$} \\
\hline $\begin{array}{r}2 \\
4 \\
7 \\
16 \\
32\end{array}$ & $\begin{array}{l}2 \cdot 74 \\
2 \cdot 53 \\
2 \cdot 36 \\
2 \cdot 04 \\
1 \cdot 73\end{array}$ & $\begin{array}{l}0 \cdot 30 \\
0 \cdot 39 \\
0 \cdot 42 \\
0 \cdot 45 \\
0 \cdot 46\end{array}$ & $\begin{array}{r}3 \cdot 58 \\
-3 \cdot 52 \\
3 \cdot 38 \\
3 \cdot 17 \\
3 \cdot 00\end{array}$ & $\begin{array}{l}0.44 \\
0.50 \\
0.50 \\
0.58 \\
0.71\end{array}$ & $\begin{array}{l}0.92 \\
1 \cdot 13 \\
1 \cdot 30 \\
1.62 \\
1 \cdot 93\end{array}$ \\
\hline \multicolumn{6}{|c|}{ At $\mathrm{pH} 8$} \\
\hline $\begin{array}{r}1 \\
\mathbf{2} \\
\mathbf{4} \\
\mathbf{6} \\
\mathbf{9} \\
\mathbf{1 3}\end{array}$ & $\begin{array}{l}2 \cdot 28 \\
2 \cdot 08 \\
1 \cdot 72 \\
1 \cdot 61 \\
1 \cdot 36 \\
1 \cdot 17\end{array}$ & $\begin{array}{l}0 \cdot 35 \\
0 \cdot 42 \\
0 \cdot 39 \\
0 \cdot 38 \\
0 \cdot 35 \\
0 \cdot 28\end{array}$ & $\begin{array}{l}\mathbf{3} \cdot 47 \\
\mathbf{3} \cdot 42 \\
\mathbf{3} \cdot 18 \\
\mathbf{3} \cdot 02 \\
\mathbf{2} \cdot 77 \\
\mathbf{2} \cdot 55\end{array}$ & $\begin{array}{l}0.72 \\
0.82 \\
0.97 \\
0.93 \\
0.96 \\
1.00\end{array}$ & $\begin{array}{l}1.38 \\
1.48 \\
1.94 \\
2 \cdot 05 \\
2 \cdot 30 \\
2 \cdot 49\end{array}$ \\
\hline \multicolumn{6}{|c|}{ At $\mathrm{pH} 9$} \\
\hline $\begin{array}{l}1^{\frac{1}{2}} \\
2 \\
4\end{array}$ & $\begin{array}{l}1 \cdot 89 \\
1.57 \\
1 \cdot 17 \\
0.97\end{array}$ & $\begin{array}{l}0 \cdot 63 \\
0 \cdot 48 \\
0 \cdot 42 \\
0 \cdot 31\end{array}$ & $\begin{array}{l}3 \cdot 38 \\
2 \cdot 92 \\
2 \cdot 64 \\
2 \cdot 44\end{array}$ & $\begin{array}{l}0 \cdot 76 \\
0 \cdot 77 \\
0 \cdot 95 \\
1 \cdot 06\end{array}$ & $\begin{array}{l}1 \cdot 77 \\
2 \cdot 09 \\
2 \cdot 49 \\
2 \cdot 69\end{array}$ \\
\hline \multicolumn{6}{|c|}{ At $\mathrm{pH} 10$} \\
\hline $\begin{array}{l}1^{\frac{1}{2}} \\
2\end{array}$ & $\begin{array}{l}0.90 \\
0.67 \\
0.57\end{array}$ & $\begin{array}{l}0.45 \\
0.45 \\
0.40\end{array}$ & $\begin{array}{l}2 \cdot 44 \\
2 \cdot 27 \\
2 \cdot 14\end{array}$ & $\begin{array}{l}0.99 \\
1.05 \\
1.07\end{array}$ & $\begin{array}{l}2 \cdot 76 \\
2 \cdot 99 \\
3 \cdot 09\end{array}$ \\
\hline
\end{tabular}

The lanthionine-S present in the wools was calculated on the assumption that any $S$ which is not present either as thiol- or disulphide-S, $\mathrm{S}$ as $\mathrm{SO}_{4}^{=}$, $\mathrm{Br}$-oxidizable-S, methionine-S $(0 \cdot 10 \%)$ is present as lanthionine-S. "Further, if it be assumed the wool has not lost any $\mathrm{S}$ during growth or conversion into combed wool, then the totalrS of the untreated wool is equal to the sum of the original cystine-S plus the methionine-S. On this assumption, the 
original cystine-S is $3 \cdot 66 \%$, and by subtracting the observed values of the thiol-plus the disulphide-S from this value, the loss of disulphide-S before or during the treatments with buffers was calculated.

This method of calculating the lanthionine-S content of the wool is indirect and consequently not of a high order of accuracy. Moreover, it may include unidentified forms of organic S-compounds, and some direct method of estimation would therefore be preferable. Hess \& Sullivan (1942) have described a method of estimating lanthionine directly by reducing the lanthionine to cysteine and some other unstated product with HI. Attempts have been made to repeat this work on both alkali-treated wool and analytically pure lanthionine, but no evidence of reduction to cysteine by $\mathrm{HI}$ could be obtained. In the circumstances therefore only a calculated value for lanthionine can be quoted.

The results of these calculations confirm the conclusions of Cuthbertson \& Phillips (1945), that about half the original disulphide-S of wool is converted by alkalis into lanthionine-S. Assuming the original virgin wool contained $3 \cdot 66 \%$ disulphide-S, then the maximum amount of lanthionine-S to be expected is $0.91 \%$. This value is sometimes exceeded slightly, particularly at the higher $\mathrm{pH}$ values, probably because the lanthionine-S is calculated as a percentage of the weight of the anhydrous wool after treatment. Some of the wool, however, is dispersed, the loss in weight reaching about $10 \%$ for the longer periods of boiling in buffer of $\mathrm{pH} 10$.

After prolonged boiling in the neutral buffer, and for shorter periods in the alkaline buffers, more disulphide-S is lost by the wool than corresponds to the lanthionine formed. Cuthbertson \& Phillips (1945) have provided evidence that when this occurs, the second half of the combined cystine is decomposing to combined $\alpha$-aminoacrylic acid (reaction 1 ).

\section{The reaction between alkali-treated wools and $\mathrm{NaHSO}_{3}$}

Disulphide-S fraction $(A+B)$. Previous work has shown that when wool is treated with solutions of $\mathrm{NaHSO}_{3}$ only part of the combined cystine, called fraction $(A+B)$, reacts to give thiol-and $S$-cysteinesulphonate groups (equation (2); Elsworth \& Phillips, 1941 ; Middlebrook \& Phillips, 1942a). The amount of the combined cystine which reacts is dependent on the bisulphite concentration, $\mathrm{pH}$ and temperature, but under the optimum conditions little more than half of the total combined cystine will react in this manner. Of the fraction which does react, subfraction $A$ can be readily reconverted to disulphide by rinsing the bisulphited wool in water.

In order to compare the behaviour of alkalitreated wool with that of untreated wool towards solutions of $\mathrm{NaHSO}_{3}$ of different concentrations, a virgin root wool, prepared by Cuthbertson \& Phillips (1945) was boiled for $3 \mathrm{hr}$. with a buffer of pH 8. Samples of this wool were then immersed for $17 \mathrm{hr}$. in $\mathrm{NaHSO}_{3}$ solutions of different concentrations. Part of each sample of bisulphited wool was hydrolyzed before and part after rinsing with water. In Fig. 1 the thiol-S contents of the hydrolysates of

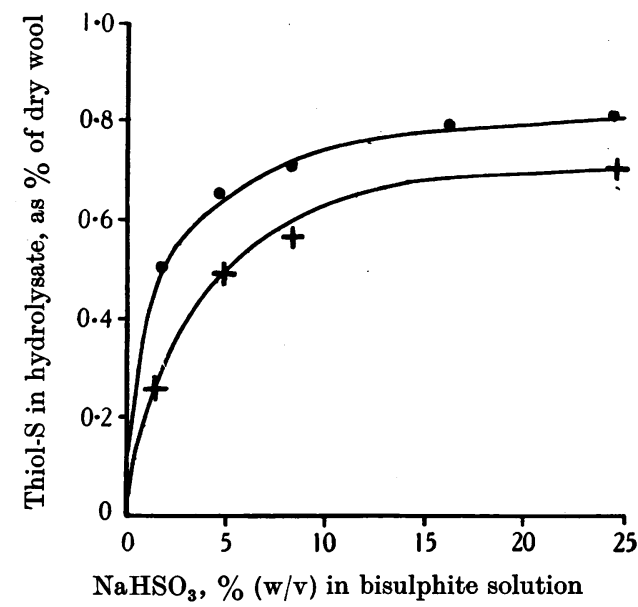

Fig. 1. $\bullet$ Unrinsed, alkali-treated wool after bisulphiting. +-+ Rinsed, alkali-treated wool after bisulphiting.

the wools are plotted against the concentrations of the $\mathrm{NaHSO}_{3}$ solutions in which they were bisulphited, and comparison with similar graphs obtained by Middlebrook \& Phillips (1942a) shows that the extent of the reaction between alkali-treated wools and $\mathrm{NaHSO}_{3}$ is influenced by the concentration of the $\mathrm{NaHSO}_{3}$ in the same manner as the reaction between untreated wool and $\mathrm{NaHSO}_{3}$. It is also evident from Fig. 1 that subfraction $A$ is destroyed by the alkali treatment more rapidly than is subfraction $B$.

Table 2 gives the results of the analyses of the alkali-treated wools of Table 1 after they had been bisulphited and also after they had been bisulphited and rinsed in water. The values quoted for fraction $(A+B)$ and subfraction $B$ are the means of four concordant determinations. It will be seen that the $(A+B)$ fraction of the disulphide-S of the untreated wool was $1.84 \%$, corresponding to half the assumed disulphide-S of the virgin wool (3.66\%). As the severity of the alkaline treatment increases, fraction $(A+B)$ decreases and is almost completely destroyed by boiling the wool for $\frac{1}{2} \mathrm{hr}$. with buffer of pH 10. Further, subfraction $A$ decomposes very rapidly even at $\mathrm{pH} 8$.

Tables 1 and 2 show that as fraction $(A+B)$ becomes smaller, the percentage of lanthionine-S in the wool increases. This is brought out more clearly 
Table 2. The combined cystine-S present as subfractions $\boldsymbol{A}$ and $\boldsymbol{B}$ in untreated and buffer-treated wools

\begin{tabular}{|c|c|c|c|}
\hline $\begin{array}{c}\text { Duration } \\
\text { of buffer } \\
\text { treatment } \\
(\mathbf{h r} .) \\
0\end{array}$ & $\begin{array}{c}\text { Fraction } \\
(A+B), \\
\text { as } S \\
(\%) \\
1.84\end{array}$ & $\begin{array}{c}\text { Sub- } \\
\text { fraction } B, \\
\text { as } \mathrm{S} \\
(\%) \\
1.02\end{array}$ & 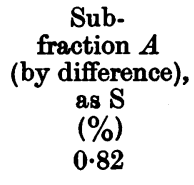 \\
\hline & \multicolumn{2}{|c|}{ At pH 7} & . \\
\hline $\begin{array}{r}2 \\
4 \\
7 \\
16 \\
32\end{array}$ & $\begin{array}{l}1 \cdot 62 \\
1 \cdot 34 \\
1 \cdot 23 \\
1 \cdot 06 \\
0 \cdot 90\end{array}$ & $\begin{array}{l}0.94 \\
0.88 \\
0.90 \\
0.81 \\
0.72\end{array}$ & $\begin{array}{l}0 \cdot 68 \\
0 \cdot 46 \\
0 \cdot 33 \\
0 \cdot 25 \\
0 \cdot 18\end{array}$ \\
\hline \multicolumn{4}{|c|}{ At $\mathrm{pH} 8$} \\
\hline $\begin{array}{r}1 \\
2 \\
4 \\
6 \\
9 \\
13\end{array}$ & $\begin{array}{l}1 \cdot 14 \\
0.95 \\
0 \cdot 82 \\
0 \cdot 54 \\
0.52 \\
0.53\end{array}$ & $\begin{array}{l}0 \cdot 85 \\
0 \cdot 77 \\
0 \cdot 65 \\
0.54 \\
0 \cdot 45 \\
0 \cdot 35\end{array}$ & $\begin{array}{l}0 \cdot 29 \\
0 \cdot 18 \\
0 \cdot 17 \\
0 \cdot 00 \\
0 \cdot 07 \\
0 \cdot 18\end{array}$ \\
\hline & \multicolumn{3}{|c|}{ At $\mathrm{pH} 9$} \\
\hline $\begin{array}{l}1^{\frac{1}{2}} \\
2 \\
4\end{array}$ & $\begin{array}{l}0.79 \\
0.65 \\
0 \cdot 46 \\
0 \cdot 34\end{array}$ & $\begin{array}{l}0.73 \\
0.63 \\
0.46 \\
0.28\end{array}$ & $\begin{array}{l}0.06 \\
0.02 \\
0.00 \\
0.04\end{array}$ \\
\hline \multicolumn{4}{|c|}{ At $\mathrm{pH} 10$} \\
\hline $1^{\frac{1}{2}}$ & $\begin{array}{l}0.20 \\
0 \cdot 14 \\
0 \cdot 14\end{array}$ & $\begin{array}{l}0 \cdot 23 \\
0 \cdot 17 \\
0 \cdot 16\end{array}$ & $\begin{array}{l}0.00 \\
0.00 \\
0.00\end{array}$ \\
\hline
\end{tabular}

by the upper curve of Fig. 2, which was fitted to the experimental points using the method of least squares. This curve was not significantly different statistically from a straight line. Since this line has a slope indicating that almost exactly two equivalents of disulphide-S disappear for each equivalent of lanthionine-S produced, it is clear that the disulphide-S of wool which reacts with $\mathrm{NaHSO}_{3}$ is also the fraction which is converted to lanthionine by alkalis and also that lanthionine is probably the only organic S-compound produced by the action of alkalis on wool. A detailed statistical examination of the analyses of the wools treated at $\mathrm{pH} 7$ gave further support to these conclusions. The rate of loss of $\mathrm{S}$ by destruction of fraction $(A+B)$ did not differ by an amount which was statistically significant from twice the rate at which lanthionine-S is produced in the wool.

Disulphide-S fraction $(C+D)$. By subtracting fraction $(A+B)$ from the total thiol- plus disulphide-S of the wools, the disulphide-S of fraction $(C+D)$ can be calculated (Table 3 ). It is not greatly affected by boiling the wool at pH 7, but at higher pH values it undergoes greater change, although even at $\mathrm{pH} 10 \mathrm{a}$ small fraction persists and accounts for almost all of the disulphide-S that remains in the wool. If fraction $(A+B)$ is the source of the lanthionine produced by the treatment of the wool with mild alkalis, then fraction $(C+D)$ is the cystine which decomposes to give combined $\alpha$-aminoacrylic acid (reaction 1). The amount of fraction $(C+D)$ that decomposes in this manner can be calculated. First, the disulphide-S lost by the wool during treatment is equal to the total-S of the original wool minus the sum of the $S$ lost during treatment, the $S$ present as $\mathrm{SO}_{4}^{=}$and the $\mathrm{Br}$-oxidizable-S. Secondly,

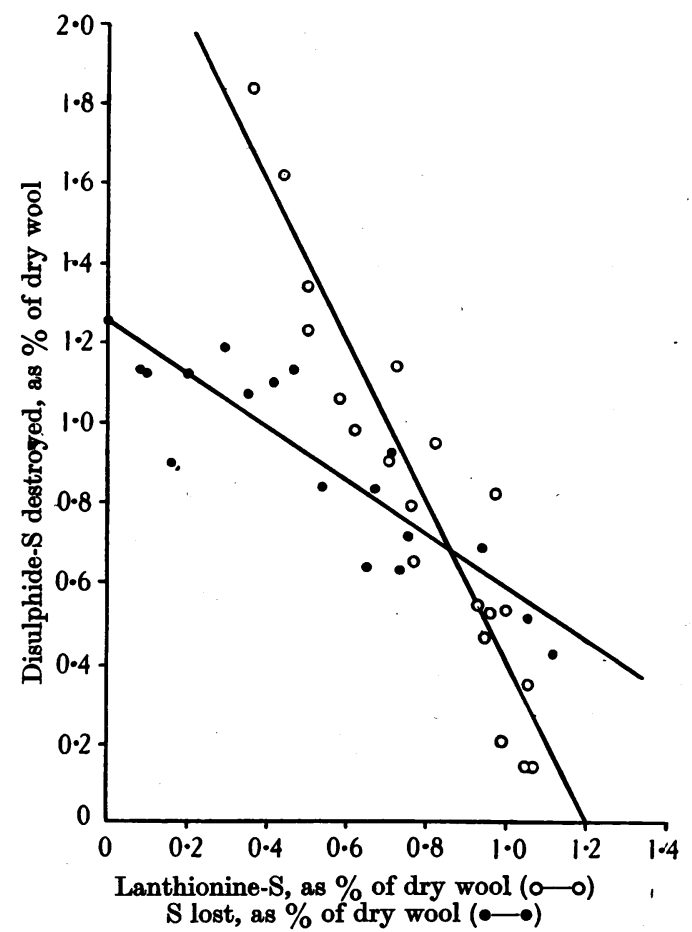

Fig. 2. $\multimap$ Conversion of disulphide-S fraction $(A+B)$ into lanthionine-S. $\bullet-$ Conversion of disulphide-S fraction $(C+D)$ into combined $\alpha$-aminoacrylic acid.

some of the disulphide-S lost is converted into lanthionine and the amount is equal to twice the increase in lanthionine-S. The disulphide-S converted to combined $\alpha$-aminoacrylic acid is therefore equal to the disulphide-S lost minus the increase in lanthionine-S of the treated over that of the untreated wool. The results of these calculations are given in Table 3.

The results obtained at $\mathrm{pH} 7$ were examined statistically. Fraction $(C+D)$ and the disulphide-S converted to combined $\alpha$-aminoacrylic acid were each plotted against the logarithm of the duration of treatments. Using the method of least squares, straight lines were fitted to the points obtained. The slope of these lines showed that at any given time the rate of loss of $S$ was not significantly different from the rate of disappearance of fraction $(C+D)$, thus providing evidence that this fraction yields $\alpha$-aminoacrylic acid. In addition, fraction 
$(C+D)$ was plotted against the $\mathrm{S}$ lost to give $\alpha$-aminoacrylic acid. Using the method of least squares, the best straight line fitting the experimental points was determined (lower curve of Fig. 2).

Table 3. The combined cystine-S present as fraction $(C+D)$ in untreated and buffer-treated wools and the $\mathrm{S}$ lost during buffer treatment with the formation of combined $\alpha$-aminoacrylic acid

\begin{tabular}{|c|c|c|}
\hline $\begin{array}{c}\text { Duration } \\
\text { of buffer } \\
\text { treatment } \\
\text { (hr.) }\end{array}$ & $\begin{array}{c}\text { Fraction } \\
(C+D) \\
(\%)\end{array}$ & $\begin{array}{c}S \text { lost with } \\
\text { formation of } \\
\alpha \text {-aminoacrylic acid } \\
(\%)\end{array}$ \\
\hline \multirow[t]{2}{*}{0} & $1 \cdot 26$ & $(0 \cdot 0)$ \\
\hline & At $\mathrm{pH} 7$ & . \\
\hline $\begin{array}{r}2 \\
4 \\
7 \\
16 \\
32\end{array}$ & $\begin{array}{l}1 \cdot 12 \\
1 \cdot 19 \\
1 \cdot 13 \\
0.98 \\
0 \cdot 83\end{array}$ & $\begin{array}{l}0.24 \\
0.38 \\
0.42 \\
0.54 \\
0.54\end{array}$ \\
\hline & At $\mathrm{pH} 8$ & \\
\hline $\begin{array}{r}1 \\
2 \\
4 \\
6 \\
9 \\
13\end{array}$ & $\begin{array}{l}1 \cdot 14 \\
1 \cdot 13 \\
0.90 \\
1.07 \\
0.84 \\
0.64\end{array}$ & $\begin{array}{l}0 \cdot 08 \\
0 \cdot 12 \\
0 \cdot 08 \\
0 \cdot 30 \\
0 \cdot 58 \\
0 \cdot 64\end{array}$ \\
\hline 13 & At $\mathrm{pH} 9$ & \\
\hline $\begin{array}{l}1^{\frac{1}{2}} \\
2 \\
4\end{array}$ & $\begin{array}{l}1 \cdot 10 \\
0.92 \\
0 \cdot 71 \\
0 \cdot 63\end{array}$ & $\begin{array}{l}0 \cdot 29 \\
0 \cdot 87 \\
0 \cdot 74 \\
0 \cdot 57\end{array}$ \\
\hline & At $\mathrm{pH} 10$ & \\
\hline $\begin{array}{l}1^{\frac{1}{2}} \\
2\end{array}$ & $\begin{array}{l}0.70 \\
0.53 \\
0.43\end{array}$ & $\begin{array}{l}0 \cdot 89 \\
0.91 \\
0.99\end{array}$ \\
\hline
\end{tabular}

The slope of this line does not show the expected $1: 1$ relationship between disulphide-S destroyed and $S$ lost with the formation of $\alpha$-aminoacrylic acid, but indicates that 1.5 equivalents of combined $\alpha$-aminoacrylic acid are formed for each equivalent of fraction $(C+D)$ destroyed. It is possible that this lack of agreement between hypothesis and experiment is due to the inaocuracy of the results when small losses of $S$ occur to give combined $\alpha$-aminoacrylic acid. This may be due partly to experimental error, but in addition, our assumption that the $S$ in the original wool which cannot be accounted for either as disulphide, thiol, $\mathrm{SO}_{4}^{=}$, or $\mathrm{Br}$-oxidizable-S is entirely lanthionine-S may not be correct. This $\mathbf{S}$ may be present partly as some other S-containing amino-acid derived from cystine by the combined action of light and air and breaking down on hydrolysis in a manner similar to the disulphide-S of fraction $(C+D)$. Some evidence supporting this conclusion was obtained when the untreated wool was boiled with feebly acid buffers. As shown in Table 4, some 'lanthionine-S' was removed, and since lanthionine is not likely to be decomposed by boiling buffers of low acidity, the small amount of $S$ lost may come from some unidentified S-containing amino-acid.

Table 4. The S-distribution of wool before and after boiling in feebly acid buffer

\begin{tabular}{|c|c|c|c|c|c|}
\hline $\begin{array}{l}\text { pH of } \\
\text { buffer }\end{array}$ & $\begin{array}{l}\text { Dura- } \\
\text { tion of } \\
\text { treat- } \\
\text { ment } \\
\text { (hr.) }\end{array}$ & $\begin{array}{c}\text { Total-S } \\
(\%)\end{array}$ & $\begin{array}{c}\text { Thiol- } \\
\text { + disul- } \\
\text { phide-S } \\
(\%)\end{array}$ & $\begin{array}{c}\text { Br-oxidiz- } \\
\text { able-S } \\
+\mathrm{SO}_{4}^{=}, \\
\text {as } \mathrm{S} \\
(\%)\end{array}$ & $\begin{array}{c}\text { Lanthio- } \\
\text { nine-S } \\
(\%)\end{array}$ \\
\hline - & 0 & $3 \cdot 76$ & $3 \cdot 10$ & $0 \cdot 20$ & $0 \cdot 36$ \\
\hline 5 & 2 & $3 \cdot 56$ & 3.08 & $0 \cdot 17$ & 0.21 \\
\hline 4 & $\frac{1}{2}$ & 3.77 & $3 \cdot 17$ & 0.34 & $0 \cdot 16$ \\
\hline 4 & $2^{2}$ & $3 \cdot 58$ & 3.05 & $0 \cdot 23$ & 0.20 \\
\hline 4 & 4 & 3.56 & 3.07 & $0 \cdot 16$ & 0.23 \\
\hline
\end{tabular}

The action of $\mathrm{pH} 8$ buffer on extended wool fibres

The results of the analysis of this extended wool after boiling in pH 8 buffer and also after the alkalitreated wool had been bisulphited are given in Table 5. The S-distribution of the alkali-treated wool is the same as that of the unextended wool after similar treatment (Table 1). There thus appears to be no difference in the reactivities of the disulphide-S linkages of stretched and unstretched wool fibres towards boiling pH 8 buffer. When the extended alkali-treated wool was bisulphited, it gave a slightly larger $(A+B)$ fraction, and subfraction $B$ was also somewhat larger than was obtained on bisulphiting the unextended alkali-treated wool. The observed differences are, however, within the limits of experimental error.

Table 5. The S-distribution of extended wool fibres after boiling with $\mathrm{pH} 8$ buffer and after subsequent treatment with $\mathrm{NaHSO}_{3}$

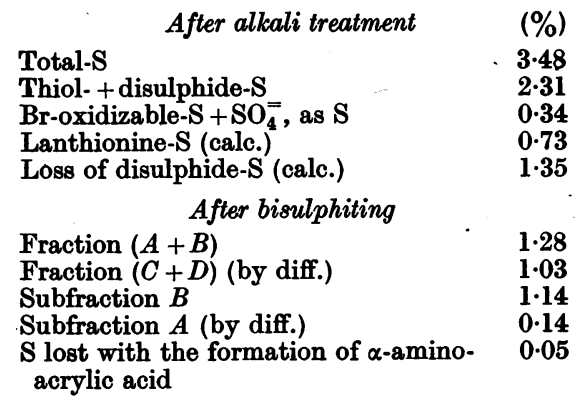

\section{DISCUSSION}

The present experiments enable us to give the following more detailed picture of the reactivities of the four subfractions into which we have divided the combined cystine-S of wool (Middlebrook \& Phillips, 1942a). 


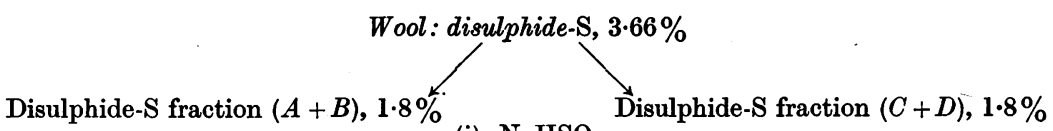

(i) $\mathrm{NaHSO}_{3}$

Subfraction $A(0.8 \%)$ gives water-labile $-\mathrm{SH}$ and $\mathrm{NaO} . \mathrm{SO}_{2} \cdot \mathrm{SCH}_{2}$-groups; subfraction $B(1 \cdot 0 \%)$ gives water-stable $-\mathrm{SH}$ and $\mathrm{NaO} \cdot \mathrm{SO}_{2} \cdot \mathrm{SCH}_{2}$-groups.
Subfraction $C(0.8 \%)$ is inert. Subfraction $D(1.0 \%)$ decomposes (particularly above room temperatures) and yields combined $\alpha$-aminoacrylic acid.

(ii) Formaldehyde (Middlebrook \& Phillips, 1942b)

Subfraction $B$ reacts at $70^{\circ}$ and $\mathrm{pH} 5 \cdot 6$.

Reacts very slowly, if at all, at $70^{\circ}$ and $\mathrm{pH} 5 \cdot 6$.

(iii) Alkalis

Converted into lanthionine. Subfraction $A$ changes more rapidly than subfraction $B$.

It was previously suggested (Middlebrook \& Phillips, $1942 a$ ) that subfraction $D$ might yield lanthionine when wool was treated with warm $\mathrm{NaHSO}_{3}$. More recently we have tried without success to isolate this acid, by the method of Horn et al. (1941), from a wool which had been treated with $\mathrm{NaHSO}_{3}$ at $70^{\circ}$. Since we found that such wools yield pyruvic acid when hydrolyzed, it now appears probable that, when subfraction $D$ decomposes, one molecule of combined $\alpha$-aminoacrylic acid is produced for each disulphide group destroyed. Our evidence as to the nature of the other product of this decomposition is still incomplete: it may be either a thiol group or a further molecule of $\alpha$-aminoacrylic acid.

The above scheme suggests that a clear-cut difference exists between fraction $(A+B)$ and fraction $(C+D)$. Fraction $(A+B)$ gives definite reactions under mild experimental conditions with all three reagents. On the other hand, fraction $(C+D)$ reacts only under more severe experimental conditions, such as increase in temperature and longer periods of treatment at higher alkalinities, and even then some residual disulphide-S, which we have called subfraction $C$, tends to remain unchanged.

The isolation by Hess \& Sullivan (1939) of a substance identified tentatively as $\alpha$-dihydroxy $\beta$-dithiopropionic acid from hydrolysates of deaminated wool suggests that some of the amino groups of a portion of the combined cystine of wool may be free. If this were so it might explain the existence of more than one type of combined cystine in wool. We have been unable, however, to eonfirm the conclusion of Hess \& Sullivan (1939), and in addition have found that $\alpha$-dihydroxy $\beta$-dithiopropionic acid, prepared by Westerman \& Rose's method (1928), is largely destroyed by hydrolysis with $\mathrm{Sn}$ and $\mathrm{H}_{2} \mathrm{SO}_{4}$, the method used by Hess \& Sullivan (1939) to hydrolyze their deaminated wool. Patterson, Geiger, Mizell \& Harris (1941) have also examined the hydrolysates of deaminated wool and have determined by titration the number of free carboxyl and amino groups in intact wool in excess of the number that can be attributed to the dicarboxylic and
Both subfractions give $\alpha$-aminoacrylic acid: subfraction $C$ slowly.

diamino acids. They concluded that little, if any, of the combined cystine of wool exists with either free carboxyl or amino groups.

The difference between fractions $(A+B)$ and $(C+D)$ may arise because fraction $(A+B)$ is more accessible than fraction $(C+D)$. Another cause of the difference may be that the reactions of fraction $(A+B)$ are more rigidly controlled by the structure of the protein molecules so that the $S$ atoms of this fraction cannot become widely separated when the disulphide linkages are broken. The properties of this fraction agree, therefore, with the accepted view that the polypeptide chains of wool are cross-linked by cystine.

There is some evidence that when fraction $(C+D)$, or more particularly subfraction $D$, is broken, a new line of cleavage is produced in the wool micelles which facilitates their dispersal. For example, wool resists dispersal by hot weak alkalis that only convert fraction $(A+B)$ into lanthionine, but is dispersed by cold strong alkalis that not only convert fraction $(A+B)$ into lanthionine but also decompose fraction $(C+D)$. Again, when fraction $(A+B)$ is broken either by cold $\mathrm{NaHSO}_{3}$ or thiolacetic acid (Middlebrook \& Phillips, 1942a), the wool swells but remains intact and shows little tendency to disperse. On the other hand, when treated with $\mathrm{NaHSO}_{3}$ at $70^{\circ}$, which decomposes fraction $(C+D)$ and converts fraction $(A+B)$ to thiol and $S$-cysteinesulphonate groups, then the wool tends to disintegrate and disperse.

Such observations lend support to the view that fraction $(C+D)$ may not be, like fraction $(A+B)$, between the polypeptide chains. Thus it might be suggested tentatively that one or both of the subfractions of fraction $(C+D)$ subdivides pairs of polypeptide chains into shorter lengths of the conventional pattern, cross-linked by fraction $(A+B)$ (shown on p. 23).

The difference between the reactivities of subfractions $A$ and $B$ is slight. Indeed, at present, it is possibly misleading to give numerical values to these separate subfractions, since their relative sizes are dependent on the physico-chemical condi- 
tions under which the thiol and $S$-cysteinesulphonate groups of subfraction $A$ are reconverted into disulphide-S. The difference between subfractions $A$ and $B$ may therefore be due to their environment: one subfraction may be arranged along the chains in close proximity to the more polar side-chains, whereas the other may have the less polar sidechains as neighbours.
$(C+D)$ is converted into combined $\alpha$-aminoacrylic acid by alkalis and also by warm solutions of $\mathrm{NaHSO}_{3}$, but does not react with $\mathrm{NaHSO}_{3}$ at room temperature.

2. Each fraction of the combined cystine has been divided into two subfractions. Subfraction $A$ yields lanthionine more rapidly and at lower alkalinities than does subfraction $B$. Subfraction $A$

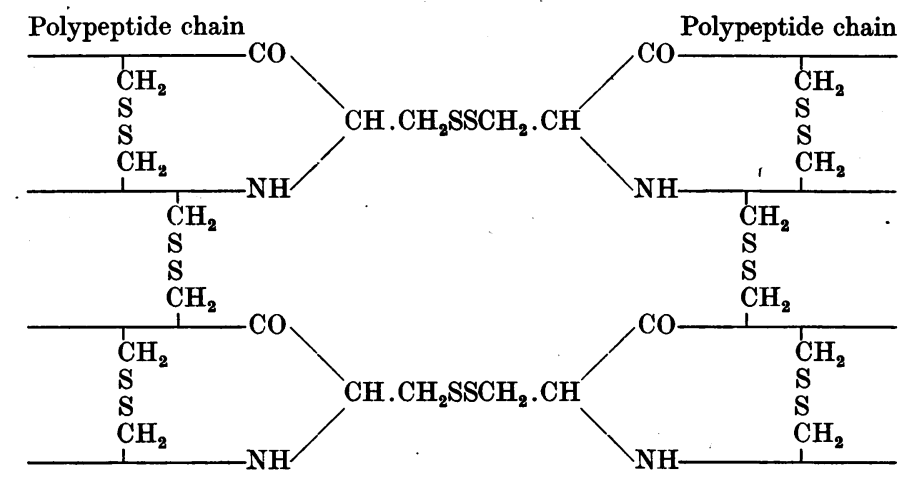

The difference between subfractions $C$ and $D$ appears to be of a more complex character. Subfraction $D$ yields $\alpha$-aminoacrylic acid fairly readily, but subfraction $C$ is the most chemically inert of the four subfractions.

\section{SUMMARY}

1. The combined cystine of wool has been divided into two equal fractions called $(A+B)$ and $(C+D)$ which differ in their mode of reaction with weak alkalis and $\mathrm{NaHSO}_{3}$. Fraction $(A+B)$ gives combined lanthionine when the wool is treated with alkalis, and thiol and $S$-cysteinesulphonate groups when the wool is treated with $\mathrm{NaHSO}_{3}$. Fraction yields water-labile thiol and $S$-cysteinesulphonate groups, whereas the thiol and $S$-cysteinesulphonate groups derived from subfraction $B$ are water-stable. Subfraction $D$ is converted to combined $\alpha$-aminoacrylic acid by alkalis and $\mathrm{NaHSO}_{3}$ more readily than is subfraction $C$.

3. No significant difference has been found between the reactivities towards weak alkalis of unstretched wool fibres and wool fibres that had been stretched $\mathbf{3 0} \%$.

The authors are indebted to Mr W. L. Semple for the statistical analysis of their results. Thanks are due to the Council of the Wool Industries Research Association for permission to publish this paper.

\section{REFERENCES}

Astbury, W. T. \& Street, A. (1931). Philos. Trans. A, 230, 75.

Baernstein, H. D. (1936). J. biol. Chem. 115, 25.

Bergmann, M. \& Stather, F. (1926). Hoppe-Seyl. Z. 152, 189.

Blumenthal, D. \& Clarke, H. T. (1935). J. biol. Chem. $110,343$.

Cuthbertson, W. R. \& Phillips, H. (1945). Biochem. J. $39,7$.

Elsworth, F. F. \& Phillips, H. (1941). Biochem. J. 35, 135. Hess, W. C. \& Sullivan, M. X. (1939). J. biol. Chem. 128, 93.

Hess, W. C. \& Sullivan, M. X. (1942). J. biol. Chem. 146, 15.
Horn, M. J., Jones, D. B. \& Ringel, S. J. (1941). J. biol. Chem. 138, 141.

Middlebrook, W. R. \& Phillips, H. (1942a). Biochem. J. 36, 428.

Middlebrook, W. R. \& Phillips, H. (1942b). Biochem. J. 36, 294.

Patterson, W. L., Geiger, W. B., Mizell, L. R. \& Harris, M. -(1941). Bur. Stand. J. Res., Wash., 27, 89.

Shinohara, K. (1935a). J. biol. Chem. 109, 665.

Shinohara, K. (1935b). J. biol. Chem. 112, 671, 683.

Speakman, J. B. (1936). J. Soc. Dy. Col., Bradford, 52, 335.

Westerman, B. D. \& Rose, W. C. (1928). J. biol. Chem. $79,413$. 